九州雨会誌 $32(6): 820 \sim 832,1979$.

\title{
定型試料（金型）を用いたレジン重合後の変形に関する研究
}

九州歯科大学大学院歯学研究科第一補緅学専攻（指導：豊田静夫教授）

滰豊

昭和54年 1 月 24 日受付

（本論文の要旨は，昭和52年 5 月 21 日の第37回九州歯科学会総会，昭和52年11月 24 日の第64回日本補経歯科学 会総会において発表した。またての論文の一部は博友会の援助によるものである））

\section{Fundamental Studies with Experimental Metal Models on Deformation after Polymerization of Dental Resins}

Yutaka Taki

First Department of Prosthetic Dentistry (Director: Prof. Shizuo Toyoda)

Kyushu Dental College, Kitakyushu, Japan

In the course of some forty years since the adaptation of acrylic resin by liquidpowder polymerization in makig dentures, modifications and improvements have been made in its properties and polymerization techniques. Although heat curing type resin with plaster cores is in main use currently, the use of pour type resin and self curing type resin in also on the increase clinically.

Many reports have been made to date on the studies of these resins, but the matter that which polymerization technique may be the most clinically favorable still remains unsettled.

In the present paper, therefore, an investigation was made of the effect on the resin test plates of the difference in the kinds of resin, cores, polymerization techniques. For the study, two types of experimental metal models of upper denture and resin test plates of heat curing type resin, pour type resin, and self curing type resin were prepared.

The results obtained were as follows :

1. Measurement of thermal conduction of plaster, silicone and agar, used for cores, revealed that plaster showed the best conduction, under given conditions, then agar and silicone followed in order.

2. In dimensional accuracy and adaptability, self curing type resin was superior to heat curing type resin in both plaster core method and silicone core method.

3. As the core materials, silicone core method has less inner stress because of its smooth surface. On the other hand, this method was slightly inferior to plaster core method in dimensional accuracy and adaptability.

4. Heating factor during polymerization affected the dimensional accuracy and adaptability of the polymerized resin test plates. 
5. Higher temperature for water-bath for submersion of the test plates after polymerization released inner stress sooner and at a high rate in time.

6. In the form of the resin test plates, shallow palate type showed less deformation rate and less degree of change with time.

\section{緒言}

歯科用アクリル樹脂は1936年にドイッでPaladon，同 ビ頃イギリスで Kallodent，アメリカではVernonite という商品名で登場した。わが国では1940年に大阪工業 試験所の大田がアクリル樹脂を紹介し，その後，山本， 永井 $(1947)^{1}{ }^{1}$ らの研究発表がなされ今日に至っている. 崡科用アクリル樹脂が蒾科臨床において重要な役割を持 っている理由として, 何よりもすぐれた操作性, 番美性 さらには口腔内における安定性などが挙げられる。しか しての反面, 重合操作中に収縮, 変形するという久点を もっており，てれが義歯床不適合の原因の一つになると いわれている。

近年，歯科用アクリル樹脂の利点をそのまま活かして より有効に用い上うとする研究がすすめられ，短時間で 加熱重合する 方法 $\left.{ }^{2}, 3\right) ，$ 全く加熱操作しない常温重合 法" や流し込み重合法5)などが開発された。

てれまで，常温重合型レジンが義歯床用材料として用 いられなかったのは，Jeffreys (1952 $)^{6}$ ， McCracken

$(1953)^{7}$, Stanford and Burns $(1955)^{8}$, Brauer and White (1959) ${ }^{9}$ らが報告したように加熱重合型レ シンより寸法精度は優れるが，物理的性質が劣っている ためであった．しかし，歯科技術とくに印象材の進歩に より床用材料に抢いても寸法精度が問題にされ，

Anthony and Peyton (1962) ${ }^{10}$ ), Mowery and Burns (1958) 11), Woelfel and Sweeney $(1963)^{12)}$ らは，常温重合型レシンで全部床義歯を作製し加熱重合 型レシシンと比較した結果，寸法精度に優れ， 4 年間患者 に使用させても破折は認められず結果は良好であったと 報告している。

Shepard (1968) ${ }^{5)}$ らによって 流し込み法による義雨 林の作製方法が報告され，以来，多くの技術的検討や評 価がなされてきている13-18)。乙の方法の利点は，常温 重合型レシンであるため寸法精度が 良いてと，上下分 割型のフラスコを用いないため咬合高径が増大しないと と，ろう義画を寒天で埋没するためフラスコからの取り 出しが容易であること，重合後のレジンと埋没型材の分 離がよいので表面研磨が容易であることなどである。乙 れに対し欠点は，人工歯の位置移動がおこりやすいて
と，咬合高径の減少がおてること，さらにレジン菌と義 歯床との接着が不確実なことなどが挙げられる。これら の欠点を補うため，特殊石こうCore法 ${ }^{16) ， シ リ コ ー ン ~}$ Core法 ${ }^{17}$ が考案された。

以上のように各種レジンの開発，その重合技術の改良 がすすめられてきたが，臨床的立場からどのレジン重合 法が最も好ましいかは依然として疑問の余地がある．今 回，上頍義菌床を模型化した二種類の定型試料（金型） を用いて，加熱重合型と常温重合型レジンの場合は，埋 没型材をフラスコ上下盒とも石こうのみの Coreと，下 盒は石こうで上盒はシリコーンコーティングを施した石 こうCoreとし，注入型レジンの場合は，石こうと寒天 Core をそれぞれ用いて，レシン試験片を作製した。さ らに，埋没型材として用いた石しう，シリコーン，寒天 の熱伝導を測定し，レジン，埋没型材，重合方法の相違 が寸法変化, 口蓋相当プレート部の離開角度変化にどの 様な影響を及ぽすかを検討し興味ある知見を得たので報 告する.

\section{予 備 実 験}

上頢両側遊離端義雨の適応となる母模型（図 1）に対 レレジン試験床を作製して，レジン重合後の経時的形状 の変化について検討した。

\section{A 予備実験の材料}

使用しだレジンは，加熱重合型レジンである $\mathrm{G}-\mathrm{C}$ 社 製 Acron，埋没型材は， $G-C$ 社製超硬石こう Surstone

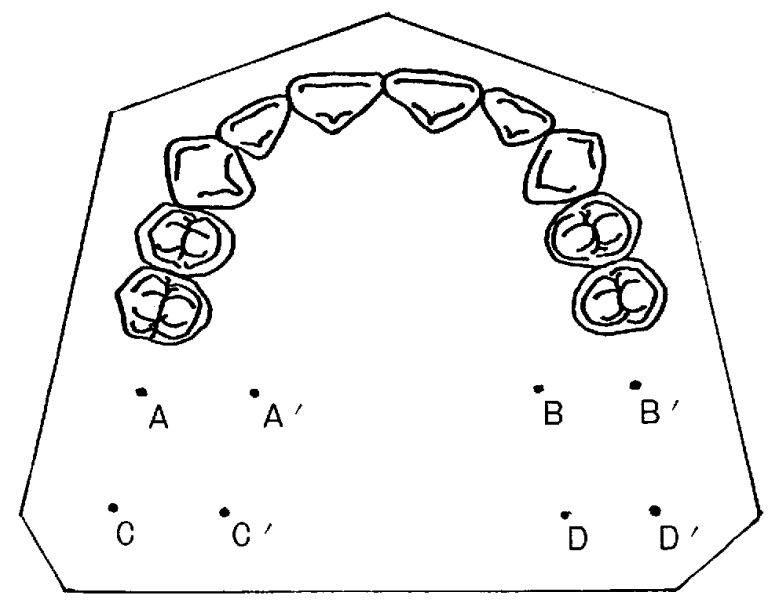

図 1 レジン試験床作製用の上顎母模型 
をそれぞれ用い通法に従ってレジン試験床を作製した。

B 予備実験の方法

母模型上の標点間 $\mathrm{A} \mathrm{A}^{\prime} \sim \mathrm{B}^{\prime} \mathrm{B}, \mathrm{CC^{ \prime }} \sim \mathrm{D}^{\prime} \mathrm{D}$ の形状 を，小坂研究所製フォームコーダEF-10型と，乙れに 連動する 渡辺測器製作所製 $\mathrm{X}$-YレコーダWX 432型で 記録し（図 2），次に重合作製したレジン試験床粘膜面 の同一標点間の形状を同様に記録した。この様にして記 録された2つの図形（図 3 ）加ら，標点 $\mathrm{AA}^{\prime}, \mathrm{B} \mathrm{B}^{\prime}$ t そ机ぞれ通る直線のなす角を離開角とし，乙の角度 $\theta_{0}$, $\theta$ 在測定して比較した。

なお，レシシン試験床の保存条件は，ヤマト工業社製恒

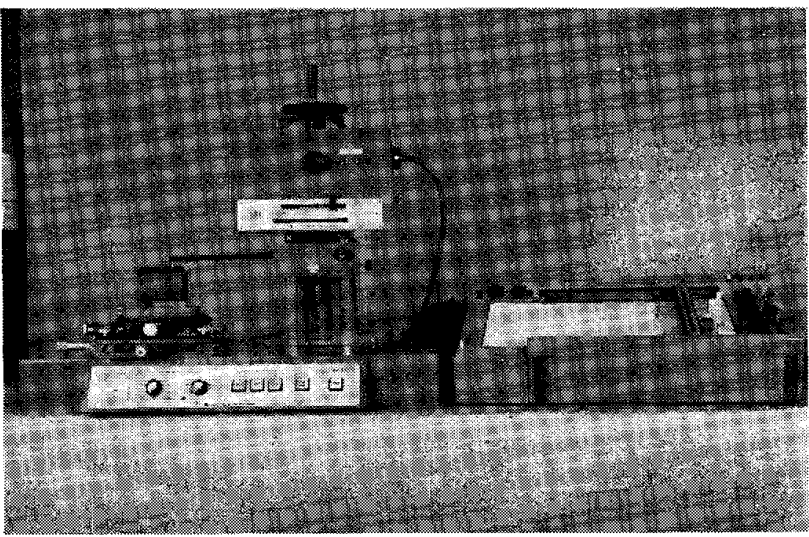

図 2 フォームコーダ E F-10型とX-Yレコーダ WX432型

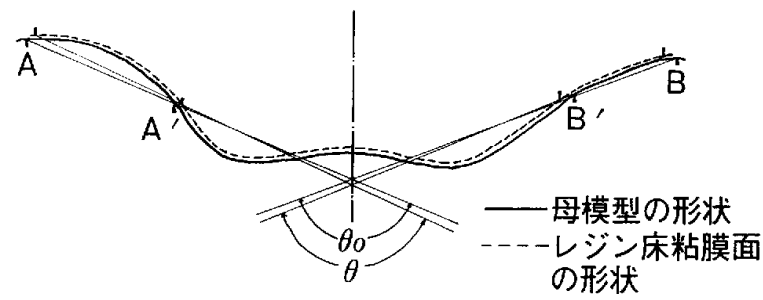

図3フォームコーダによりトレースした形状の比較

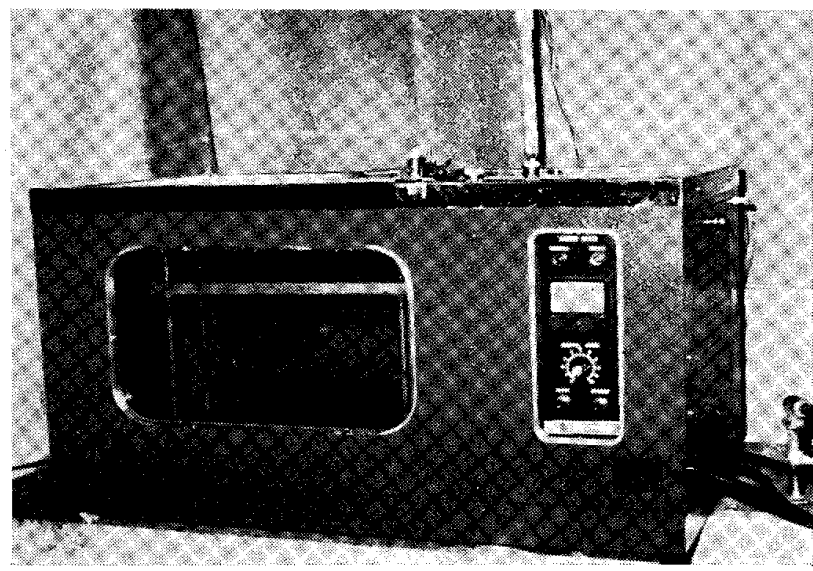

図4 恒温水槽
温水槽（図 4）を用いて， $20^{\circ} \mathrm{C} の$ 水中浸漬とした。测 定時点は, 離型直後, $1,2,3,5,7,14,21,28$ 日経過後の 9 回とし，レジン試験床は 5 個作製した。

C 予備実験

母模型の離開角度 $\theta_{0}$ とし，レシシン試験床粘膜面の離開 角度 $\theta$ との差を $\theta_{0}$ で割ったもの，すなわち $\theta_{0}-\theta / \theta_{0}$ を 変形率 $\gamma$ として, この変形率 $\gamma$ の経時的変化について調 べた（図 5 ）。

離型直後の変形率は，1.68土0.06\%であった。次に， 離型直後の変形率と28日経過後の変形率の差は，0.49\% であった。

変形率 $\gamma$ の值は，離型直後から5 日経過後まではかな り急速に変化し，その後は緩やかとなり 7 日以上経過す ると変化は見られないようになった。

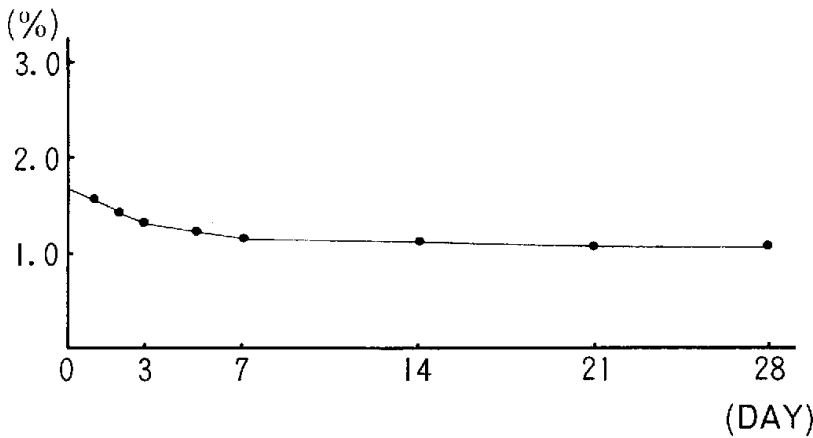

図 5 レジン試験床離開角度の経時的変化

\section{D予備実験の考察}

以上の結果から，レジン試験床は重合後離型すると， すでに変形をおてしていた。このため重合操作中に，何 かの因子が作用して変形を引き起ししたのではないかと 推測できる．乙の変形の原因の一つとして, Skinner

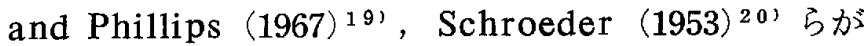
指摘している熱収縮が考えられる。しかし，熱収縮が生 じてもレジンは，埋没型材で拘束の状態にあるため自由 な変形を抢てすてとができない，したがってレジン試験 床内部に応力が生じると考えられる，乙の内部応力の発 生に関しては三宅（1978） ${ }^{211}$ の報告がある。ての内部応 力は，離型直後に全て解放するのではなく，その後も徐 々に解放がすすむためかなり長時間変形がおてるものと 思われる。

この予備実験を参考にして，次のような本実験を行っ た。 


\section{試料作製方法並びに実験材料}

\section{A 熱伀導測定用試料の作製}

フラスコ内の埋没型材に填入された各種レジンは，そ れ独自の重合操作が加えられるが，レジン重合時に関係 する熱は，外部からの熱，レジンの反応熱である。この 熱を埋没型材が吸収するか逆に断熱するかによって，レ ジンの熱収縮，重合度の進行に差が生じる，そこでまず 埋没型材の熱伝導を測定した.

図6に示すように，高さ $90 \mathrm{~mm}$ ，直径 $10 \mathrm{~mm}$ の円柱 状に，埋没型材として用いる $\mathrm{G}-\mathrm{C}$ 社製 超硬石こう Surstone，東レシリコーン S H一9550R T V，寒天は 松風社製 Cast Gel のそれぞれを作製し試料とした。な お，レジン床重合時には，フラスコ内の埋没型材の厚さ は一定でないため，てこでも熱電対一水面間距離を $7 \mathrm{~mm}, 21 \mathrm{~mm}$ の通りとした。

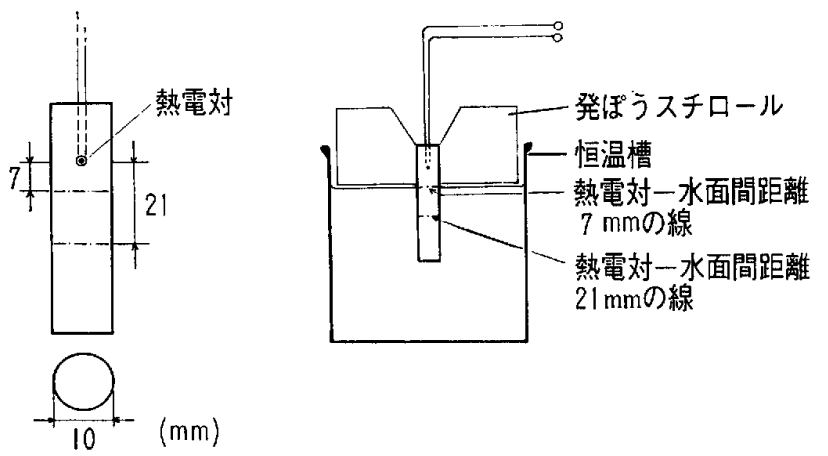

図 6 熱伝導測定用試料之試料の測定部仿
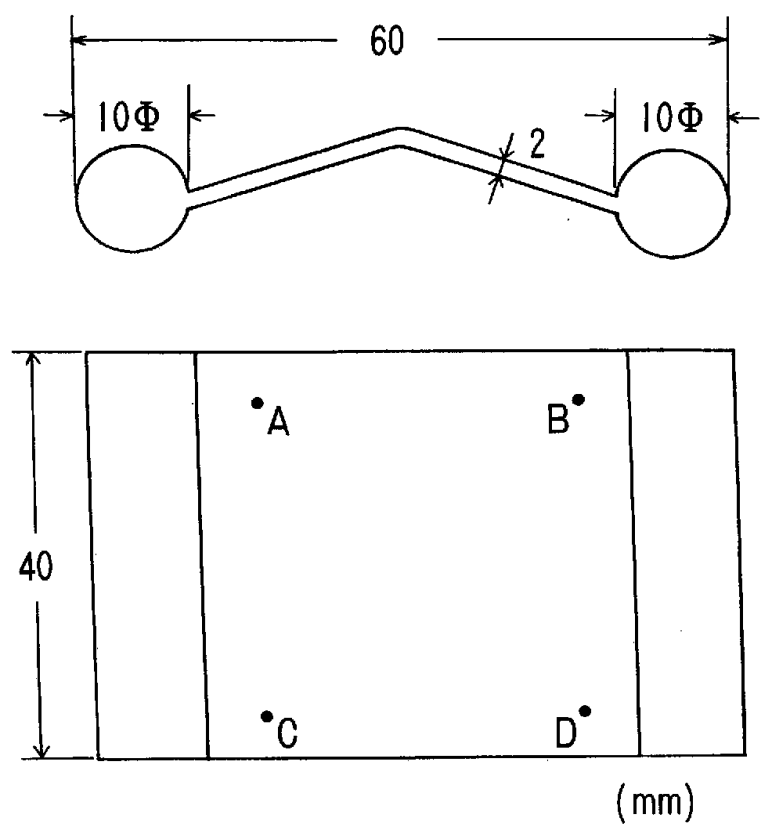

図 7 定型試料（金型）No.1タイプ

\section{B 定型試料 (金型)}

レジン試験片作製の原型となる定型試料（金型）は， 図 7，8に示すように上頻義粤床を模型化したもので, 口蓋相当プレート部の形状を変えて（深いタイプと浅い タイプ）二種類とした.プレート部には 4 個の標点を刻 んである.な抢，日蓋の浅いタイプを№.1，深いタイプ を№. 2 とした。

$$
\text { C レジン材料 }
$$

加熱重合型レジンは $\mathrm{G}-\mathrm{C}$ 社製 Acron，注入型レジ ンは松風社製 Cast Resin, 常温重合型レシシンは G-C 社製Repairsinを用いた。粉液比は，メーカーの使用説 明書に従った。

\section{D 埋没方法}

加熱重合型と常温重合型レジンに関しては，(1) $\mathrm{G}-\mathrm{C}$ 社製超硬石こう Surstone で重合用フラスコの上下盒と も埋没したもの（Plaster core type）と(2)下盒は超硬 石こうで埋没し, 上盒は工業用シリコーンである東レシ リコーン S H一9550R T V で定型試料（金型）を 2 $3 \mathrm{~mm}$ の厚さにコーティングし，その後に超硬石こうで 埋没したもの（Silicone core type）の二種類とした (図9).

注入型レジンでは，松風社製 Cast $\mathrm{Gel}$ と超硬石てう で通法に従って埋没した。なお，スプルーの位置は，気 泡の発生，重合収縮に及ぼす影響の最も少ないとされて いる肉厚部に板状のスプルーをたてた15!。
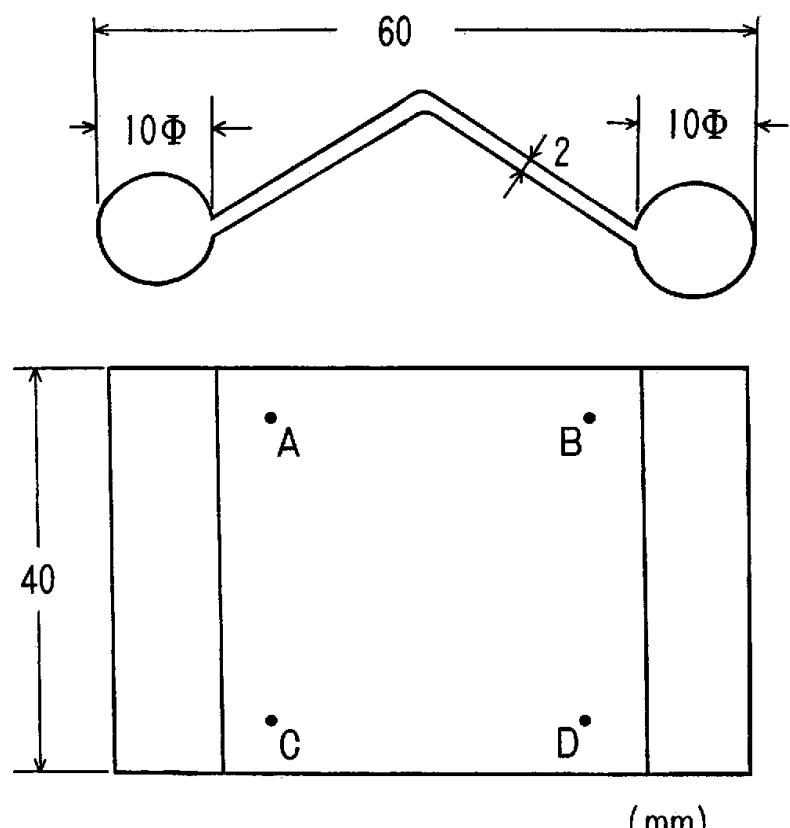

図 8 定型試料（金型）No.2タイプ 


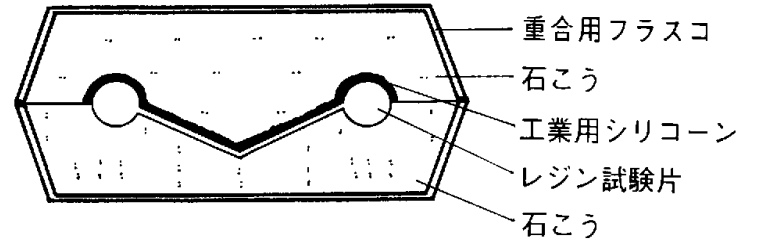

図 9 埋没型材として石こうとシリコーンを用いた 重合法

E 重合方法

Acron は，モリタ製作所製キュアリングーュニット $\mathrm{NC}-1$ 型（図10）を用い， $60^{\circ} \mathrm{C} て ゙ 60$ 分間紫留後，沸 腃水中に60分間熬留して重合を行った，その後は，室温 まで空中放冷した。

Cast Resin は, レジ注入後30分間空中放置し，松 風社製Cast Resin用重合槽で $50^{\circ} \mathrm{C} ， 30$ 分間踒留して重 合を行った。その後は, 室温まで空中放冷した。

Repairsin は, 室温で重合を行った。

\section{実 験 方 法}

A 熱伝導の測定

本実験でレシン試験片作製時に埋没型材として用いた 超硬不こう，寒天，シリコーンの熱伝導測定用試料の それぞれに，銅一コンスタンタン熱電対を埋め込んだ。

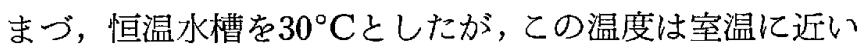

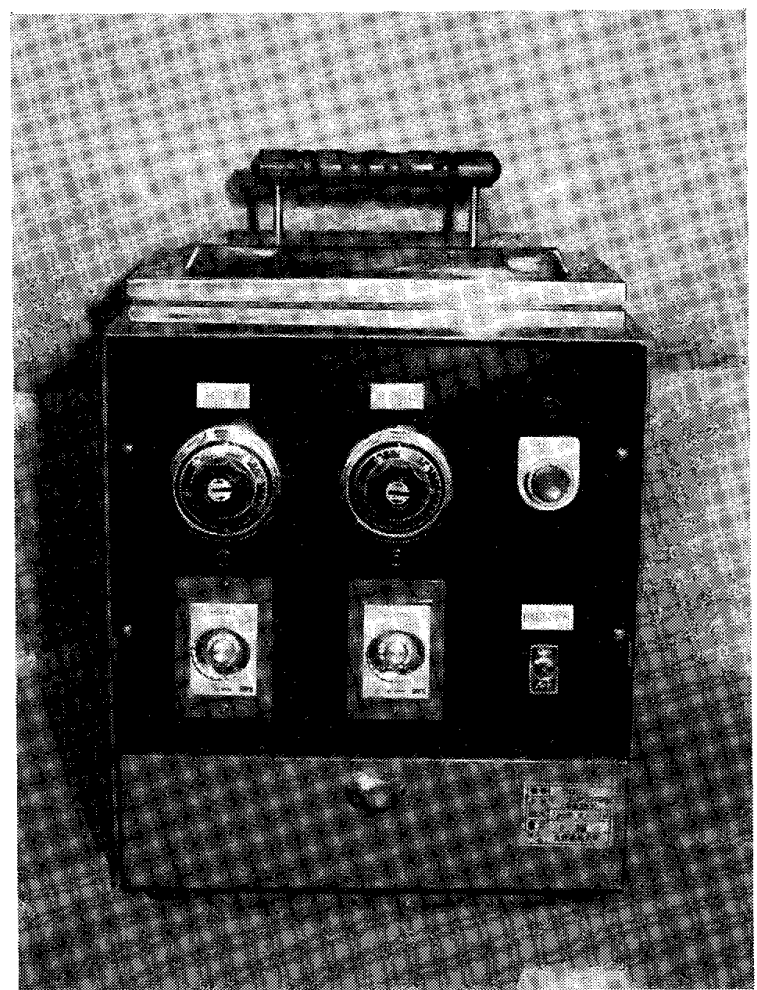

図10
キュアリング ユニット NC-1 型
ため䇪温で重合する常温重合型レシンの埋没型材として 用いる超硬石こう，およびシリコーンの試料について熱

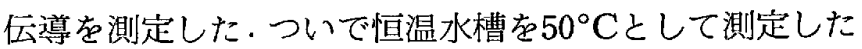
が，てれはこの温度で注入型レシンを重合させるため， 試料としては注入型レジンの埋没型材として用いられる 寒天，超便石とうとシリコーンなどを用いた。さらに恒

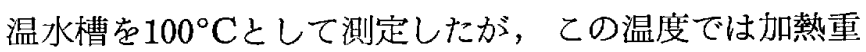
合型レジンを重合させるため, 超硬不てう，シリコーン を用いた。さらに，熱電対一水面間の距離を $7 \mathrm{~mm}$, $21 \mathrm{~mm}$ の二通りとし，との間の熱伝導を测定した（図 11） - 測定に際し他からの熱の影響をなくすため，水面 上の試料を発ぱうスチロールでおおうた。測定装置は， 松下通信社製 V P - 653 B 型で，初めの試料温度を $23^{\circ} \mathrm{C}$ とし，测定を始めた（図12）。

\section{B 寸法変化試験}

粜科技術が精度の面で進歩をとげた現在，義歯床用レ ジンの寸法精度は, 適合性に関して大きな鍵となる。そ こで, 重合操作中のさまざまな因子, 例えば, 粉液比, 加熱, 埋没型材などの相違が重合後の寸法変化にどの様 な影響を及ぼすのか，経時的に測定し検討した．

ここでは, 定型試料（金型）に刻んである標点 $\mathrm{A}$ と $\mathrm{C}, \mathrm{B}$ とD間の距離 $29.95 \mathrm{~mm}$ (网13) と, レジ試験

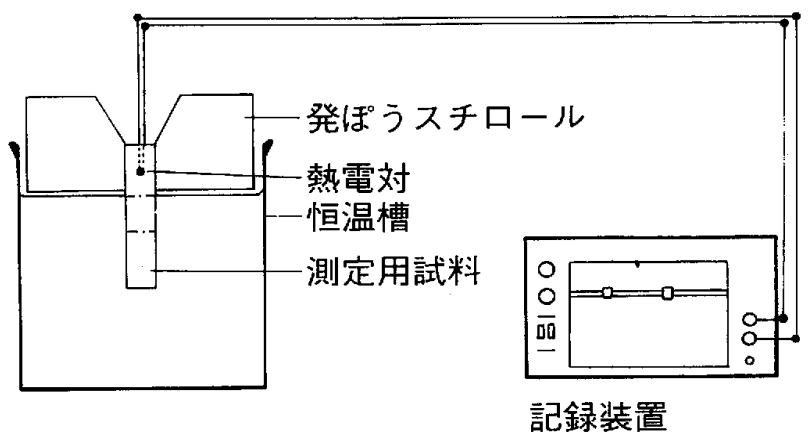

龱 11 熱伝導測定方法

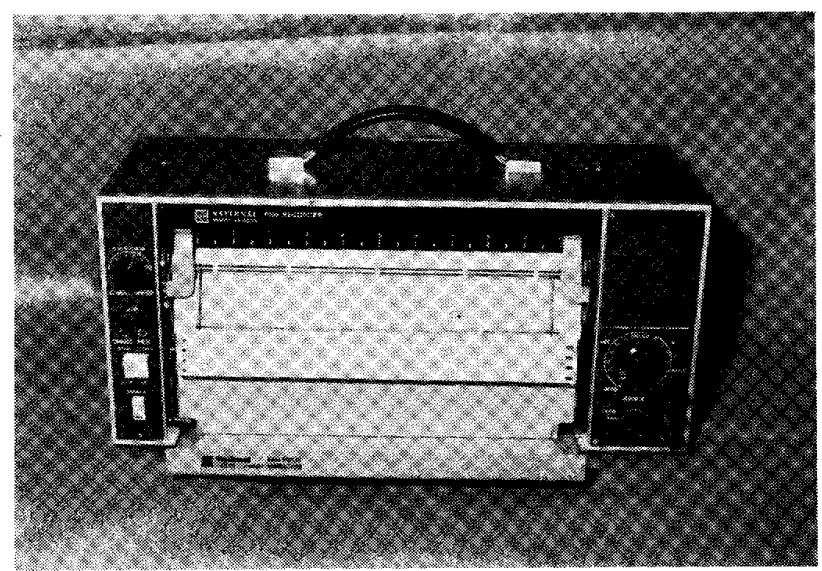

図12

$$
\text { ペンコーダ } 653 \text {-B型 }
$$


片の同じ標点間距離を中村製作所製ピカ読取顕微鏡 P R M-3 XY Z (図14) で，1/100mmの精度にて 測定し 収縮率を算出した。測定時点は, 離型直後, 1,2 , $3 ， 5 ， 7 ， 14 ， 21 ， 28$ 日経過後の 9 回とし，レジン試 験片の保存状態は $20^{\circ} \mathrm{C}, 37^{\circ} \mathrm{C}$ 環境温度とし, それぞ れの温度で恒温水槽を用い水中浸漬を行った. 各条件に ついて，5個ずつのレジン試験片を作製し，重合収縮率 の経時的変化, 変化の浸漬温度依存性について調べた。

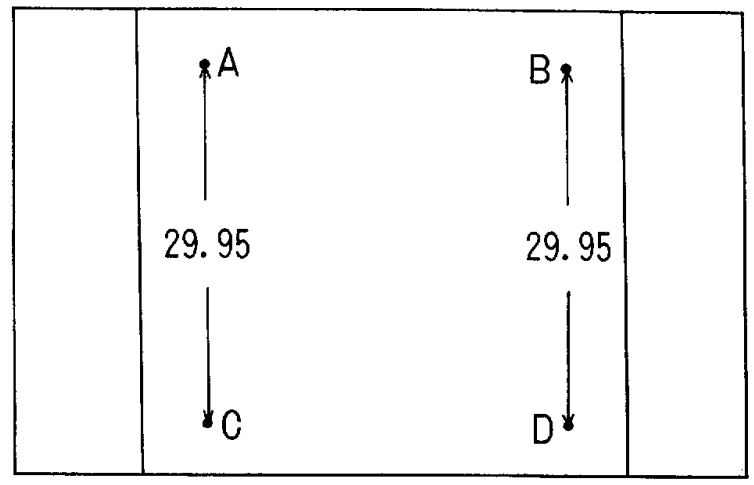

$(\mathrm{mm})$

闵13定型試料 (金型) の標点間距離

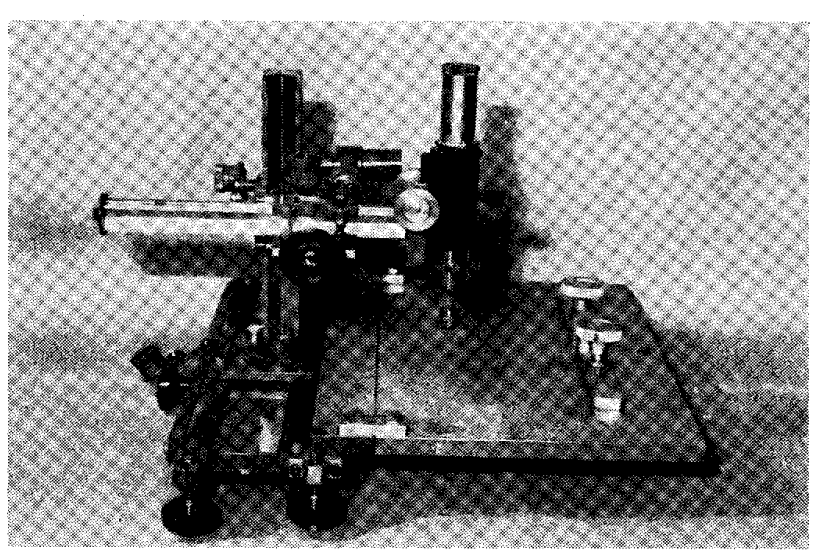

図14 読取顕 微 鏡 PRM-3 XYZ

C 口蓋相当プレート部の離開角度変化試験

義菌床適合性の良し，悪しを把握するには，レジン重 合後の寸法変化を知るだけではなく, 形状の変化をも知 る必要がある. そてで，上颚義歯床の形状を単純模型化 した二種類の定型試料（金型）を用いて，次のような実 験を行った。

定型試料 (金型) に刻んである標点 $\mathrm{A}$ と B，CとD間 の形状と，レジン試験片粘膜面の同じ標点間の形状を， 小坂研究所製フォームコーダEF-10型と，乙れに連動 する渡辺測器製作所製 X-YレコーダWX432型 でグラ フ上に記録した。こうして得た二つの図形からそれぞれ
の口蓋相当プレート部の離開角度を求め, 変形率を算出 した.なお，定型試料 (金型) のNo.1タイプの離開角度 $\theta_{0}$ は $146.21^{\circ}$, 同じく No.2タイプは $114.24^{\circ}$ である（戝 15).

レジン試験片の保存状態は， $20^{\circ} \mathrm{C}, 37^{\circ} \mathrm{C}$ 環境温度 とし，それぞれの温度で恒温水槽を用いて承中浸漬とし た. 測定時点は 離型 直後, $1,2,3,5,7,14$, 21，28日経過後の 9 回とし，レジン試験片の 定型試料 （金型）に対する変形率の経時的変化，さらにその保存 温度依存性についても調べた。

各条件について，5個づつのレジン試験片を作製し た。

\section{実 験 結 果}

A 熱伝導について

最初の試料温度を $23^{\circ} \mathrm{C}$ として测定を開始したが，試 料浸漬温度 $30^{\circ} \mathrm{C}$, 熱電対一水面間距離が $7 \mathrm{~mm}$ 場合, 超硬石てう試料は約 11 分で $27^{\circ} \mathrm{C}$ ，シリコーン試料は約 13 分で $25^{\circ} \mathrm{C}$ となり，その後は一定温度となった。 その

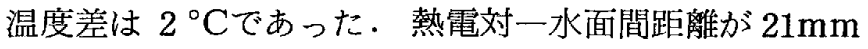
の場合，超硬石こう試料は約 12 分で $25^{\circ} \mathrm{C}$, シリコーン 試料は約 14 分で $24^{\circ} \mathrm{C}$ とり，その後は一定温度となっ た. その温度差は， $1{ }^{\circ} \mathrm{Cであった。}$

水中浸漬温度 $50^{\circ} \mathrm{C}$, 熱電刘一水面閏距離が $7 \mathrm{~mm}$ の 場合, 超硬石乙う試料は約 8 分で $45^{\circ} \mathrm{C}$, シリコーン試 料は約 12 分で $34^{\circ} \mathrm{C}$, 寒天試料は約 11 分で $37^{\circ} \mathrm{C}$ となり, その後は一定温度となった，その温度差は，超硬石こう 試料とシリコーン試料間で $11^{\circ} \mathrm{C}$, 超硬石こう試料と寒 天試料間で $8{ }^{\circ} \mathrm{C}$, シリコーン試料と寒天試料間で $3{ }^{\circ} \mathrm{C}$ であった。熱電対一水面間距離が $21 \mathrm{~mm}$ の場合, 超硬石 こう試料は約 10 分で $36^{\circ} \mathrm{C}$ ，シリコーン試料は約 14 分で $30^{\circ} \mathrm{C}$, 寒天試料は約 14 分で $31^{\circ} \mathrm{C}$ となり, その後は一定

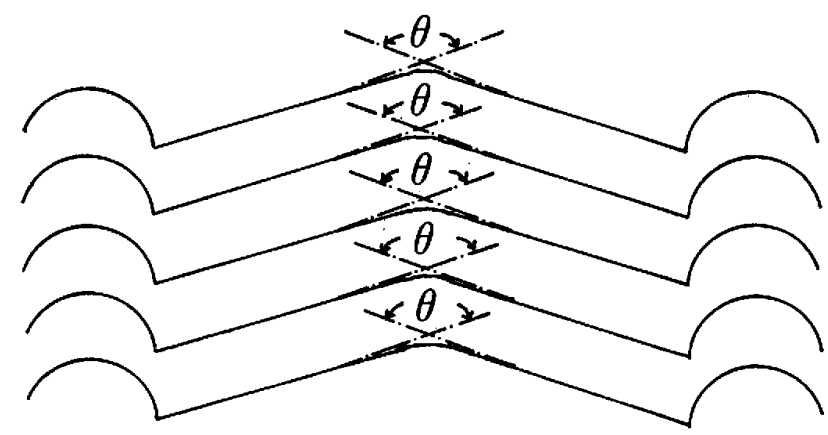

定型試料 (金型) No.1 タイプ $\theta 0=146.21^{\circ}$ 定型試料 (金型) No.2 タイプ $\theta 0=114.24^{\circ}$

図15定型試料（金型）の離開角度 


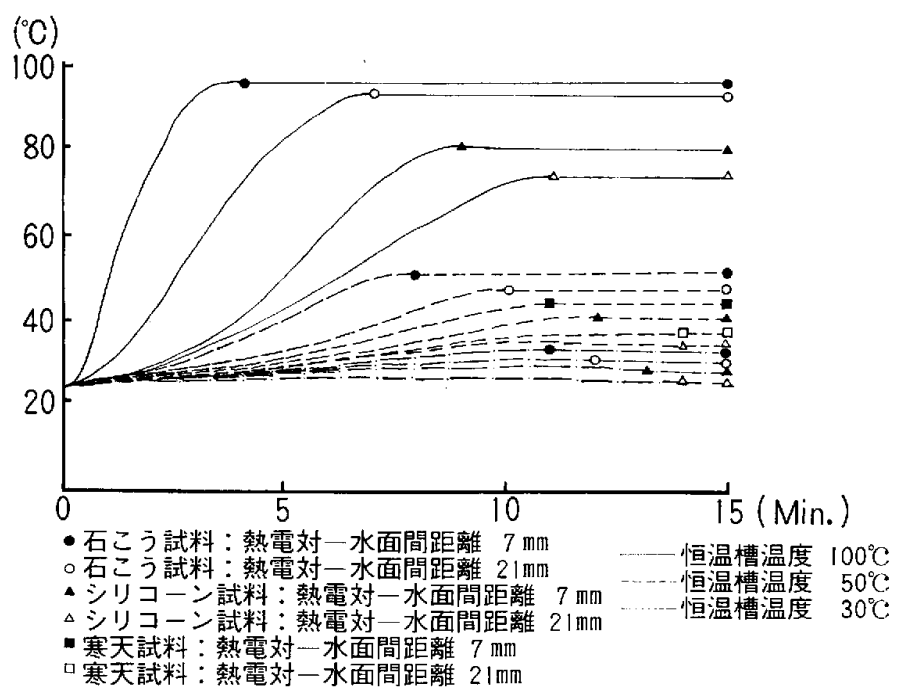

図16各埋没型材の熱伝導

温度となった。その温度差は，超硬石こう試料とシリコ ーン試料間で $6{ }^{\circ} \mathrm{C}$ ，超硬石とう試料と寒天試料間で

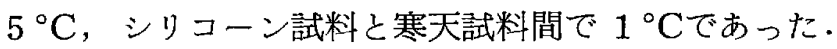

水中浸漬温度 $100^{\circ} \mathrm{C}$, 熱電対一水面間距離が $7 \mathrm{~mm} の$ 場合，超硬石乙う試料は約 4 分で $94^{\circ} \mathrm{C}$ ，シリコーン試 料は約 9 分で $80^{\circ} \mathrm{C}$ とり，その後は一定温度となった。 その温度差は， $14^{\circ} \mathrm{C}$ であった。熱電対一水面間距離が $21 \mathrm{~mm}$ の場合，超硬石こう試料は約 7 分で $92^{\circ} \mathrm{C}$, シリ コーン試料は 約 11 分で $74^{\circ} \mathrm{C}$ となり，その後は一定温度

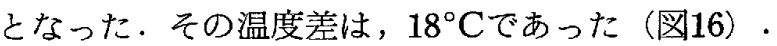

B 寸法変化試験

離型直後の収縮率は，加熱重合型レシシンの plaster core type が $0.54 \pm 0.03 \%$, silicone core type が $0.73 \pm 0.05 \%$ ，注入型レジンが $0.35 \pm 0.03 \%$ ，常温重合 型レシシンの plaster core type が $0.19 \pm 0.04 \%$, silicone core type が $0.26 \pm 0.05 \%$ であった（図17）。

離型直後と28日経過後の寸法変化率の差（経時的寸法 安定性) は, レジン試験片を $20^{\circ} \mathrm{C}$ 水中浸漬保存の場 合, 加熱重合型レジンのplaster core typeが $0.17 \%$, silicone core type が0.14\%，注入型レジンが $0.12 \%$ 常温重合型レジンの plaster core type が $0.10 \%$, silicone core type が0.09\%であった. 次に,レシン 試験片を $37^{\circ} \mathrm{C}$ 水中浸漬保存の場合，加熱重合型レジ ンの plaster core type が $0.18 \%$, silicone core typeが $0.16 \%$ ，注入型レジンが $0.13 \%$ ，常温重合型レ シンの plaster core type が $0.12 \%$, silicone core type が0.11\%であった（図18）。

経時的寸法変化をみると，各レジン試験片はいずれも 膨張傾向にあるが，離型後 $5 \sim 7$ 日以上経過すると膨張
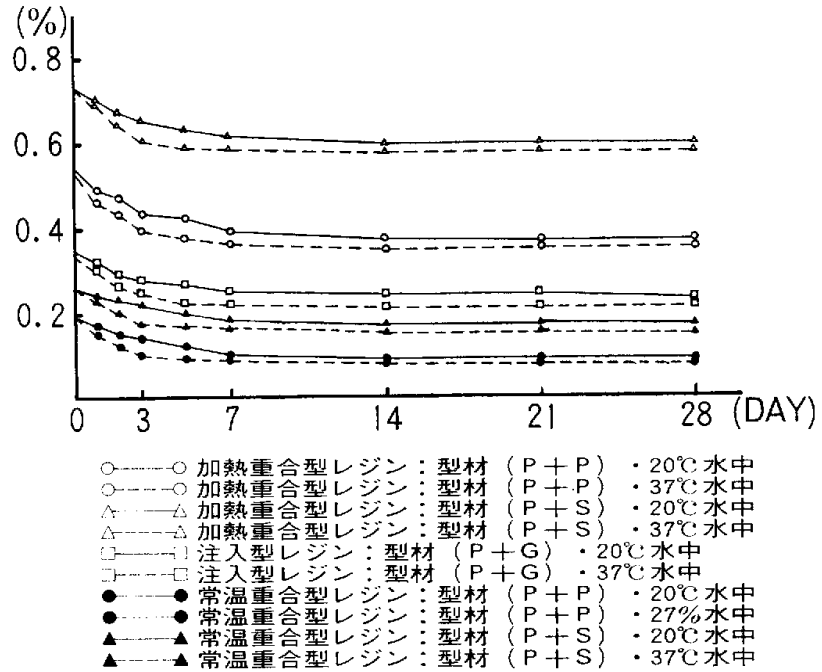

図17レジン試験片の経時的寸法変化

$(\%)$

0.2

0.1

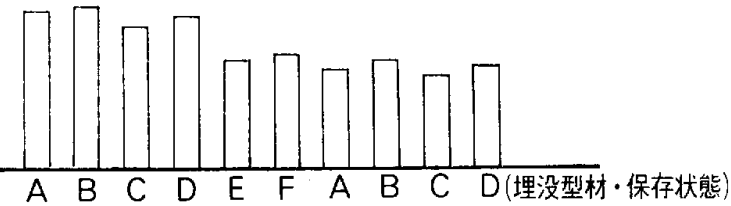

加熱重合型 注入型 常温重合型

レジン レジン レジン

$A:$ 型材 $(P+P) \cdot 20^{\circ} \mathrm{C}$ 水中 $D:$ 型材 $(P+S) \cdot 37^{\circ} \mathrm{C}$ 水中

$B:$ 型材 $(P+P) \cdot 37^{\circ} \mathrm{C}$ 水中 $E:$ 型材 $(P+G) \cdot 20^{\circ} \mathrm{C}$ 水中

$\mathrm{C}:$ 型材 $(\mathrm{P}+\mathrm{S}) \cdot 20^{\circ} \mathrm{C}$ 水中 $\mathrm{F}:$ 型材 $(\mathrm{P}+\mathrm{G}) \cdot 37^{\circ} \mathrm{C}$ 水中

図18 レシン試験片の経時的寸法変化量

傾向が減少しほとんぞ変化しなくなった。

レジン試験片寸法変化の 保存温度依存性をみると， $20^{\circ} \mathrm{C}$ 上りも $37^{\circ} \mathrm{C}$ 水中浸漬の方が，早い時期に膨張傾 向を示し, 経時的寸法変化量は大きくなった.

C 口蓋相当プレート部の離開角度変化試験

定型試料 (金型) の口蓋相当プレート部離開角度を $\theta_{0}$ とし，乙れを用いて作製したレジン試験片の離開角度を $\theta$ とした。 $\theta_{0}-\theta / \theta_{0}$ を変形率 $r$ とし, ての変形率の経 時的変化，保存温度依存性について調べた。

離型直後の変形率は, No.1 タイプのレジン試験片の場 合, 加熱重合型レジンの plaster core type が $1.21 \pm$ $0.05 \%$, silicone core type が $1.42 \pm 0.04 \%$, 注入型 レジンが $0.71 \pm 0.04 \%$, 常温重合型レジンの plaster core type が $0.42 \pm 0.03 \%$, silicone core type が $0.51 \pm 0.04 \%$ であった. N0.2 タイプのレシン試験片の場 合, 加熱重合型レジンの plaster core type が 1.99土 $0.06 \%$, silicone core type が $2.32 \pm 0.05 \%$, 注入型 
レシンが $1.19 \pm 0.05 \%$ ，常温重合型レジンの plaster core type が $0.71 \pm 0.04 \%$, silicone core type が $0.83 \pm 0.04 \%$ であった（図19〜24）.

離型直後と28日経過後の変形率の差（経時的変化量） は, No. 1 タイプのレシン試験片を $20^{\circ} \mathrm{C}$ と $37^{\circ} \mathrm{C}$ 水中浸 漬保存の場合, 加熱重合型レジンのplaster core type

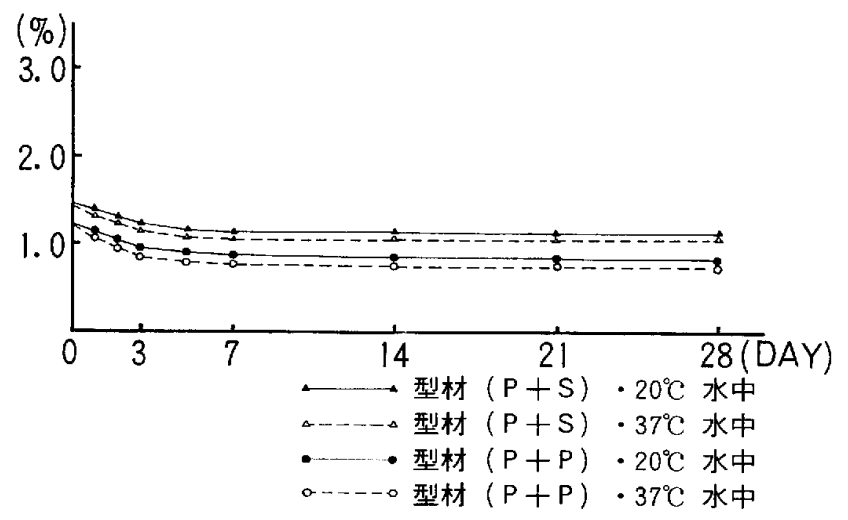

図19 加熱重合型レジンNo.1 タイプ試験片離開角 度の経時的変化

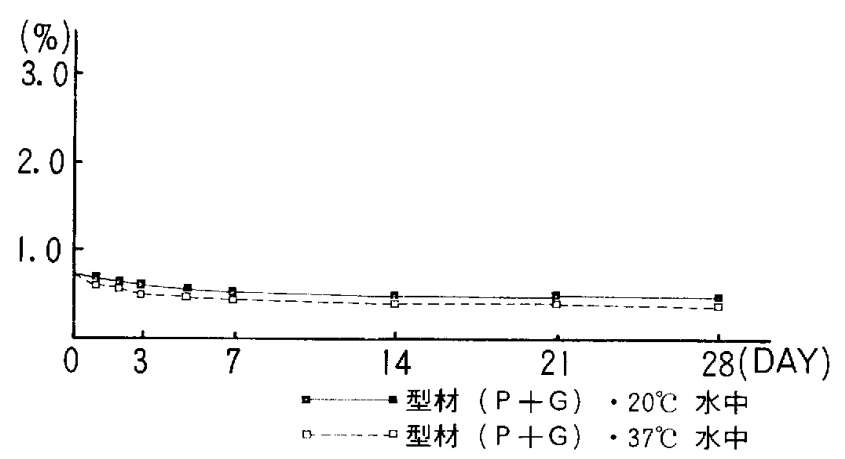

図20 注入型レシンNo. 1 タイプ試験片離開角度の 経時的変化

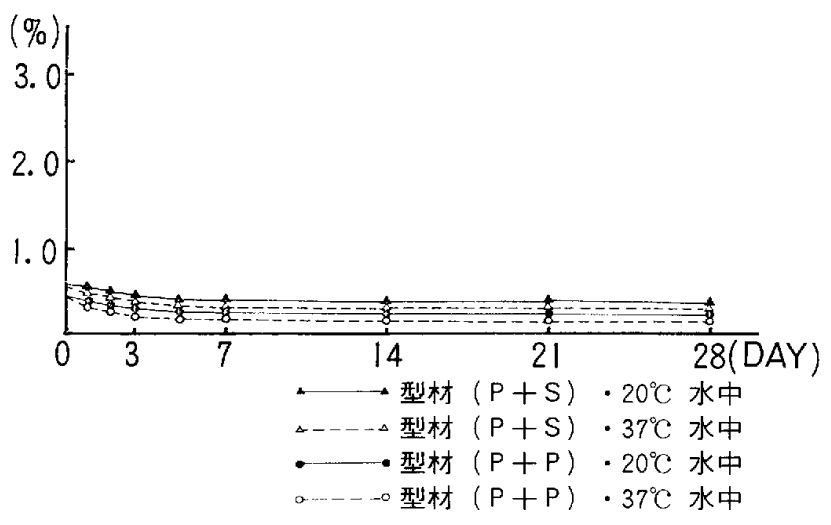

図21常温重合型レシンNo.1 タイプ試験片離開角 度の経時的変化
がそれぞれ0.22\%と0.23\%， silicone core typeが0.20 $\%$ と $0.21 \%$, 注入型レジが $0.25 \%$ と $0.26 \%$, 常温重合 型レシンの plaster core type が $0.41 \%$ と $0.42 \%$, silicone core type が $0.33 \%$ と.34\%であった.№.2夕 イプのレジン試験片を $20^{\circ} \mathrm{C}$ と $37^{\circ} \mathrm{C}$ 水中浸漬保存の場 合，加熱重合型レシンの plaster core type がそれぞ

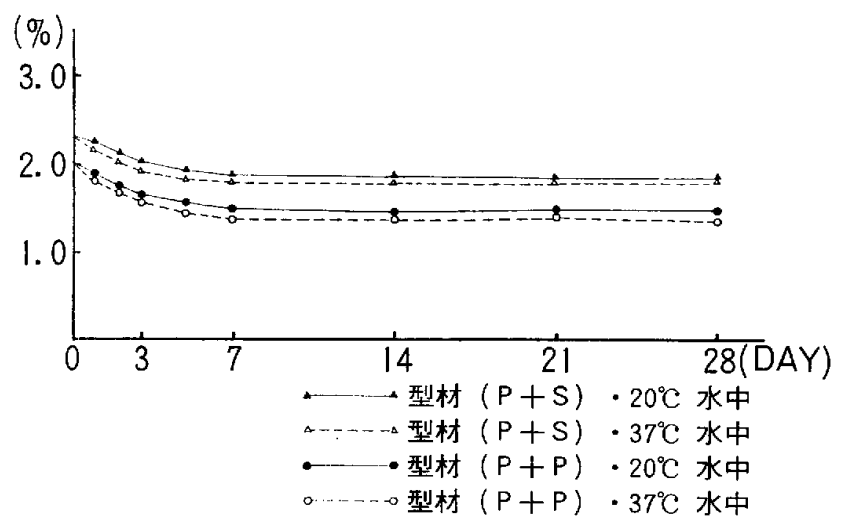

図22 加熱重合型レジンNo.2 タイプ試験片離開角 度の経時的変化

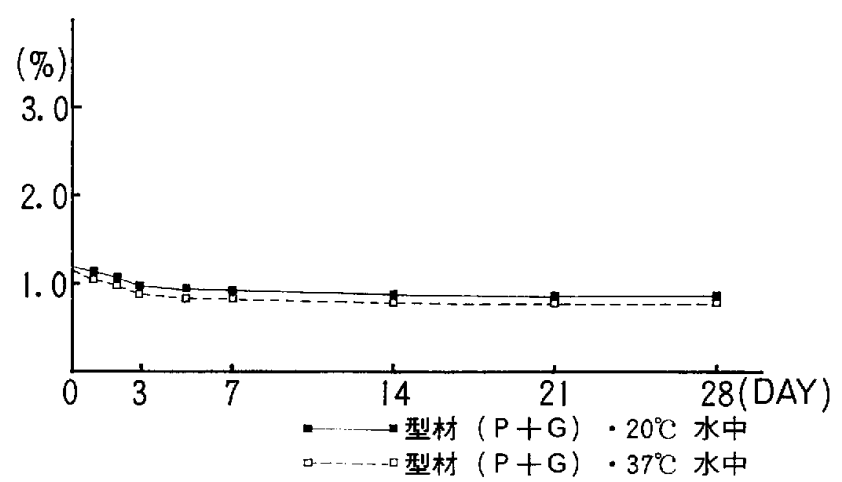

図23 注入型レシンNo.2 タイプ試験片離開角度の 経時的変化

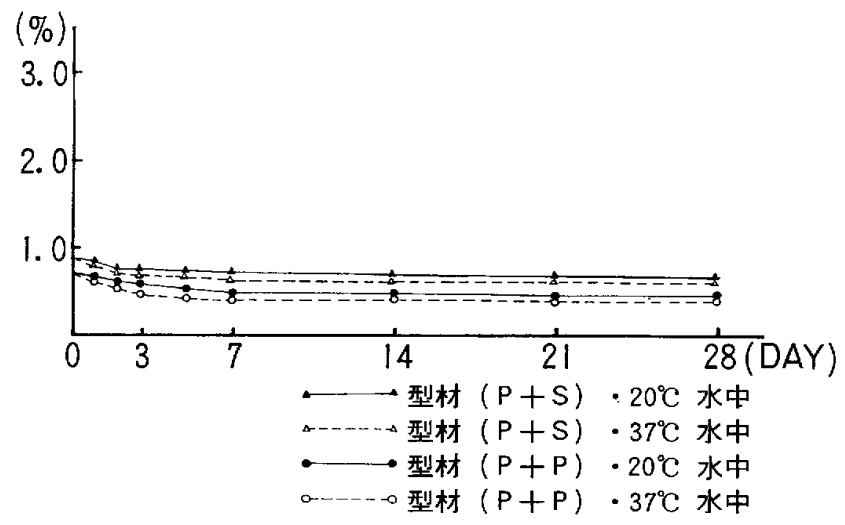

図24 常温重合型レジンNo.2 タイプ武験片離開角 度の経時的変化 


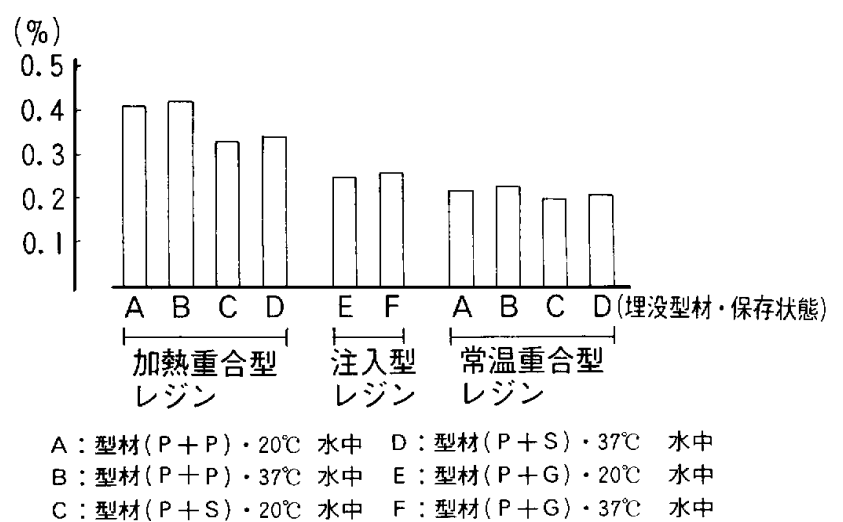

図25 No.1 タイプレシン試験片離開角度の経時 的変化量

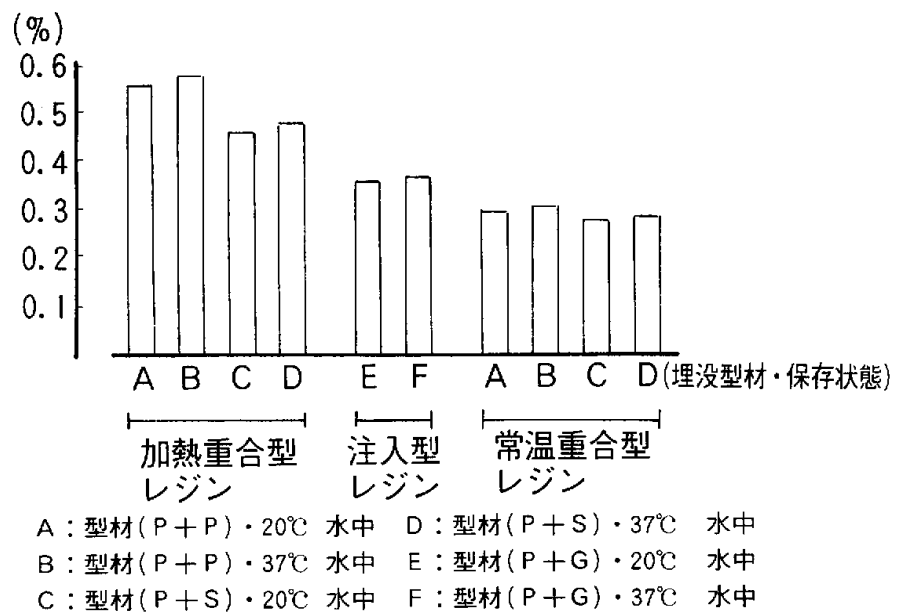

図26 No.2 タイプ レシン試験片離開角度の経時 的変化量

れ0.56\%と $0.58 \%$, silicone core type が $0.46 \%$ と $0.48 \%$, 注入型レジンが $0.36 \%$ と $0.37 \%$, 常温重合型レ ジンのplaster core typeが $0.30 \%$ と0.31\%, silicone core typeが $0.28 \%$ と $0.29 \%$ でった（図25，26）.

変形率の経時的変化をみると, 各レシン試験片は離型 後 5〜7日までにはかなりの変化を示すが，それ以後は あまり変化しなくなった。レジ試験片の変形率の保存 温度依存性をみると， $20^{\circ} \mathrm{C}$ よも $37^{\circ} \mathrm{C}$ 水中浸漬の方 が, 早い時期に変化を示し, 経時的変化量は大きくなっ た.

\section{考察}

A 熱伝導について

試料浸漬温度 $30^{\circ} \mathrm{C}$, 熱電対一水面間距離が $7 \mathrm{~mm}$ と $21 \mathrm{~mm}$ の場合, 超硬石こう試料はそれぞれ約 11 分で $27^{\circ} \mathrm{C}$ と約 12 分で $25^{\circ} \mathrm{C}$ ，シリコーン試料は約 13 分で $25^{\circ} \mathrm{C}$ と約

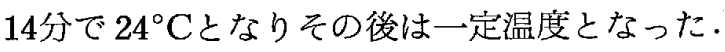

試料浸漬温度 $50^{\circ} \mathrm{C}$ ，熱電刘一水面開距離が $7 \mathrm{~mm}$ 之 $21 \mathrm{~mm}$ の場合, 超硬石こう試料はそれぞれ約 8 分で $45^{\circ} \mathrm{C}$ と約 10 分で $36^{\circ} \mathrm{C}$, シリコーン試料は約 12 分で約 $34^{\circ} \mathrm{C}$ と 14 分で $30^{\circ} \mathrm{C}$, 寒天試料は約 11 分で $37^{\circ} \mathrm{C}$ 約 14 分で $31^{\circ} \mathrm{C}$ となりその後は一定温度となった。

試料浸清温度 $100^{\circ} \mathrm{C}$, 熱電対一水面間距離が $7 \mathrm{~mm}$ と $21 \mathrm{~mm}$ の場合，超硬不乙う試料はそれぞれ約 4 分で $94^{\circ} \mathrm{C}$ と約 7 分で $92^{\circ} \mathrm{C}$, シリコーン試料は約 9 分で $80^{\circ} \mathrm{C}$ と約 11分で $74^{\circ} \mathrm{C}$ なりの後は一定温度となった。

さて，レジンの本態はいずれもメタアクリレートであ り，加熱重合型レジンが外部からの加熱により重合反応 が進行するのに対して，常温重合型レジンは化学的な反 応によって重合が進行する. 加熱重合型レジンのポリマ 一には重合促進剤として0.5〜1.0\%の過酸化ベンゾイル が含まれており重合温度が $60^{\circ} \mathrm{C}$ 以上になるととの促進 剂が分解をおこし遊離基を作る。乙の遊離基にモノマー 分子が順々に付加して重合体が成長する゙'。乙の加熱重 合型レシンの場合，外部からの熱とレジン自体の反应熱 のためレジン内ではかなり高温となるととが推测できる が，埋没型材の熱伝導の相違によりレジン重合時の温度 環境が変化するため，重合度の進行が埋没型材の種類に よって左右されることとなる。

今回，注入型レシンの重合を $50^{\circ} \mathrm{C} の$ 雰囲気下で行っ たが，乙れにレシン自体の反応熱が加わっても加熱重合 型レジン比べるとかなり低温である，さらに埋没型材 の寒天と超硬不こうに熱が奪われるととでレジンの重合 度が加熱重合型レジンど十分に進行せず，ポリマーに 末膨化の部分が残ると考えられる。とのため寒天よりも 断熱効果の高いシリコーンを埋没型材に用いる重合方法 が研究されているのもうなずけるととである17).

常温重合型レジンは室温で重合させるため, 加熱重合 型レジンのように加熱操作で過酸化ベンゾィルを活性化 するかわりに，モノマーに加えたジメチルトルイジンな どの第 3 級アミン類で過酸化ベンゾイルの分解を化学反 応的に促進させレジンの重合を進行させる.しかし，一 般に化学的に活性化させたものの重合度は, 加熱によっ て活性化させたものより低いといわれている22'．乙の ため，レシン自体の反応熱に埋没型材がどのような断熱 効果 (熱伝導) を示すかで，レジンの重合度に差が生じ るととが考えられる。三宅（1978（21'は，埋没型材に石 こうとシリコーンを用いて各種タイプのレジンで試験片 を製作し, 比容積 Tg の值を比䩙した結果, 常温重合型 レジンを石こうのみで埋没重合した場合には $\mathrm{Tg}$ が低い 
が、シリコーンで埋没重合すると， $\mathrm{Tg}$ が非常に上昇し 他のタイプのレジンの Tg に近づくと指摘している.

本実験でも型材にシリコーンを用いた場合は，他の埋 没型材よりも蓺伝導が低く断熱効果がよいためレジンの 重合反忘熱が周囲の型材に奪わわれることが少なく，レ シンの重合度が進行しやすいものと考えられる.

B 寸法変化試験について

寸法変化について重合直後の収縮率を此較すると，レ シン試験片を $20^{\circ} \mathrm{C} の$ 水中浸漬保存の場合，加熱重合型 レジンのplaster core typeが $0.54 \pm 0.03 \%$, silicone core type が $0.73 \pm 0.05 \%$ ，注入型レジンが $0.35 \pm$ $0.03 \%$, 常温重合型レジンの plaster core type が $0.19 \pm 0.04 \%$, silicone core type が0.26士0.05\%で あった。加熱重合型レジンの収縮率に比べ注入型レジ ン，常温重合型レジンのその值は約 $2 / 3 \sim 1 / 2$ であった．理 論的には, レジン重合時の粉液比を 2 とすると， $7 \%$ の 容積收縮と $2.3 \%$ 線収線をおこすが，埋没型材や加圧 方法あるいは重合方法に影響をうけるといわれている4 一方, Skinner $(1960)^{19}$, Schroeder $(1953)^{20)}$, Mowery and Burns (1958)11' らが，レシン床作製過 程中に生じる硬化収縮は, ガラス転移温度から室温まで に冷却される間の熱収縮であると述べているように，本 実験でも常温重合型レジンの収縮率が他のタイプのレジ ンより小さいのは, 重合温度と室温との差が少ないとと によるものと考えられる。

加熱重合型レジン，常温重合型レシンのどちらの場合 もモノマーの重合収縮菜は理論上同じであるが，加熱重 合型レシンの方が収縮率が大きいのは，硬化時に高温と なり重合度がかなり進み分子間の凝集力が高まったため であろう。

次に, 注入型レジと常温重合型レシンを比較してみ ると, 注入型レジンの収縮率が常温重合型レシンの収縮 率よりも大きいのは， $50^{\circ} \mathrm{C}$ 温水窝团気下で重合したた めにレシンの重合反応がこの外部温度変化に大きく左右 されたこと，常圧下で重合したととや埋没型材の相違に よるものと考えられる。

この寸法変化を加熱重合型, 常温重合型レシンの重合 に用いた埋没型材（超硬石こう，シリコーン）の相違か らみると, plaster core は表面が粗造なためレジンと の摩摖力が大きく自由な変形がおこらないが, silicone core は表面が滑沢なためレシンとの摩擦力が小さく自 由な変形がおこりやすく收縮率が大きくなったものと考 えられる。

離型直後と28日経過後の寸法変化率の差（経時的寸法
安定性〉は, レジン試験片を $20^{\circ} \mathrm{C} の$ 水中浸漬保存の場 合，加熱重合型レジンのplaster core typeが0.17\%， silicone core typeが0.14\%, 注入型レジが $0.12 \%$, 常温重合型レジンの plaster core type が $0.10 \%$, silicone core type が0.09\%であった. 次に， $37^{\circ} \mathrm{C}$ 水中浸漬保存の場合, 加熱重合型レシンのplaster core typeが $0.18 \%$, silicone core type が0.16\%, 注入型 レジンが $0.13 \%$, 常温重合型レジンの plaster core typeが $0.12 \%$, silicone core type が $0.11 \%$ あっ

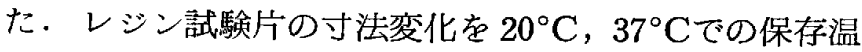
度依存性についてみると，保存温度が $37^{\circ} \mathrm{C}$ の場合は， 離型直後から 5 日経過後までにかなり急速に変化した が，その後は緩やかになった，保存温度が $20^{\circ} \mathrm{C} の$ 場合 は, 離型直後から 7 日経過後までに急速に変化したが $37^{\circ} \mathrm{C}$ 場合ほどではなく，その後は緩やかになった。 経時的寸法変化量は, 各レジン試験片とも保存温度が高 い方が大きな值であった．埋没型材の相違から経時的寸 法変化量をみると, 加熱重合型レジン, 常温重合型レジ ンでは, plaster core type の方が silicone core type よりも大きい值であった. これは, plaster core の表面が, silicone core に比べるとかなり粗造でレシ ンの重合収絔を阻止する摩擦力となるため，レシン内部 に応力が生じると考えられる。

$\mathrm{C}$ 口蓋相当プレート部の離開角度変化試験につい $\tau$

レジン武験片の適合性判定法として, 丸岡 $(1971)^{27}$ は，(1)日腔内で直接判定する方法，(2)顎模型を用い口腔 外で判定する方法，(3)疑の形状を単純化した定型試料

（金型）を用い判定する方法などに分類した。(1)の方法 そついては, Woelfel and Paffenbarger (1965) ${ }^{23}$ ', Young $(1970)^{24}$ らが indicator-paste や石とうを用 いてその厚さを肉眼的に計測している。乙の方法は， 簡便で臨床上に応用しやすいが条件を一定化するのが大 いへん困難である，(2)の方法については，Anthony and Peyton (1962)10) らが comparator で床粘膜面 の形状を直接計測している。また，Woelfel and Paffenbarger らは，口蓋部においてレシン床と石とう 模型との間陌を，模型を切断するととにより計測してい る.(3)の方法については, Smith, et al. (1967) 28), 藤井ら $(1968)^{3}$ ', 中井ら $(1967)^{29}$, 加藤ら $(1968)^{2}$ の報告があり，レシン試験片と定型武料とを合わせその 間隙を測定している。また，原田 $(1965)^{22}$ 'は，レジン 試験片と定型試料との離開角度を計測することでレシン 試験片の変形を追求した。 
本実験は (3)の方法に 属するものであるが，定型試料 (金型) から直接レシン試験片を作製し，乙の形状をつ オームコーダとX-Yレコーダで測定するため，たびた びもとの定型試料（金型）に合わせてその適合度を見る というようなレジン試験片の変形をおてし易い計測上の 操作がないため, 正確にレシンン試験片の変形を測定でき ると思われる。

さて, No.1タイプのレジン試験片について離型直後の 変形率をみると, $20^{\circ} \mathrm{C} の$ 水中浸漬保存の場合, 加熱重 合型レシンの plaster core type が $1.21 \pm 0.05 \%$, silicone core type が $1.42 \pm 0.04 \%$, 注大型レジンが $0.71 \pm 0.04 \%$, 常温重合型レジンのplaster core type が $0.42 \pm 0.03 \%$, silicone core ty pe が $0.51 \pm 0.04 \%$ であった. 加熱重合型レシンに比べ注入型, 常温重合型 レシンンは，およそ $1 / 2 \sim 1 / 3$ の值を示した. 埋没型材の相違 からみると, 加熱重合型, 常温重合型レジンのどちらも plaster core typeの方が, silicone core typeより 小さい值であった.

次に, No. 2 タイプのレジン試験片について離型直後の 変形率をみると, $20^{\circ} \mathrm{C}$ の水中浸漬保存の場合, 加熱重 合型レジンの plaster core type が $1.99 \pm 0.06 \%$, silicone core type が $2.32 \pm 0.05 \%$, 注入型レジンが $1.19 \pm 0.05 \%$, 常温重合型レシンのplaster core type

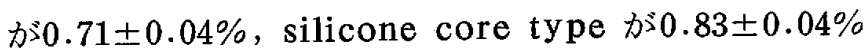
であった.てのタイプの試験片も，№.1タイプのレジン 試験片と同じく, 加熱重合型レジンに比べ注入型, 常温 重合型レシンは，およそ1/2〜1/3の值を示した。これら は, Osborne $(1947)^{30}$, Woelfel and Paffen barger $(1960)^{26}$ ) らが報告しているように，常温重合 型レジンが加熱重合型レジンよりも内部応力の発生が少 ないというととに起因し，また注入型レジンと常温重合 型レジンとを比較すると, 注入型レシンンの変形率が大き いのは, 粉液比の差, $50^{\circ} \mathrm{C}$ の温水雾囲気下で重合した こと，加圧を行なわなかったととなどによるものと考光 られる。

埋没型材の相違からみると，加熱重合型レジン，常温 重合型レジンのどちらも plaster core type の方が silicone core typeよりも変形率が小さいのは, plaster core の表面が粗造なためレジンとの摩擦力が 大きく自由な変形がおこらないが， silicone core は 表面が滑沢なためレジンとの摩擦力が小さく自由な変形 がおてりやすいためであると考えられる。

同一条件下で重合したNo. 1，№.2タイプのレジン試験 片を形状の相違からみると，No.1タイプのレシン試験片
の方が変形率は小さくなった。このことは，レジン試験 片の形状の相違により, 重合時に内部応力の発生に差が 生じたためで, №. 2 タイプのレジン試験片の方が内部応 力の発生が大きいと考壳られる.

レシンン試験片の 離型直後と 28 日 経過後の変形率の差 (経時的変化量) をみると, No.1 タイプのレジン試験片 を $20^{\circ} \mathrm{C}$ の水中浸漬保存の場合，加熱重 合型レジンの plaster core typeが $0.41 \%$, silicone core type が $0.33 \%$ ，注入型レジンが $0.25 \%$ ，常温重合型レジンの plaster core type $0.20 \%$ あった．次に，水中浸漬保存を $37^{\circ} \mathrm{C}$ に変える と, 加熱重合型レジンのplaster core typeが $0.42 \%$, silicone core type が $0.37 \%$, 注入型レジンが 0.26 $\%$, 常温重合型レジンのplaster core typeが $0.23 \%$, silicone core type が0.21\%であった.乙れをレジン の種類別にみると, 変化量の大きいものから順に, 加熱 重合型, 注入型, 常温重合型レジンとなり, 前述の Osborne らの報告したように内部応力の発生の大きい ものほど変化量が大きくなった，埋没型材の相違からみ ると, $20^{\circ} \mathrm{C}, 37^{\circ} \mathrm{C}$ のずれの水中浸漬保存の場合も， plaster core typeの方が silicone core typeよりも 大きな変化量を示した。これは，plaster coreが silicone coreよりもレシンとの摩擦力が大きく, 重合 時の内部応力も大きくなったものと考えられる.

変形率の経時的変化を, 保存温度依存性についてみる と， $37^{\circ} \mathrm{C}$ 方が $20^{\circ} \mathrm{C}$ 場合よりも離型後早い時期によ り急速な変化をし, 経時的変化量も大きくなった。

結局, 加熱重合法よりも常温重合法, さらに silicone core method 上り plaster core method の方が, 寸法変化武験, 口蓋相当プレート部の離開角度変化試験 によい值を示した。しかし，経時的な変化量をみると， 加熱重合法は, ガラス転移温度から室温までの温度差が 非常に大きいためレジンの重合収縮が他の重合法に比べ 大きくなり，てのためレジンの内部応力も当然大きくな るととが考えられる.また, plaster core method は, 重合中に生じた変形とレジンの dough に対する融通性 のないととのため内部応力の発生が大きく, 経時的な変 化量が大きくなった。一方, silicone core method は, レジンの dough に対する融通性が plaster core method の場合よりも高いため自由な変形が可能であ り, 離型直後の変形率は大きいが内部応力の発生は小さ くなったといえる。 


\section{結論}

上領義雪を模型化した二種類の定型試料（金型）を用 いて, 加熱重合型, 注入型, 常温重合型レジンの試験片 を作製し，レジンの種類，型材，重合方法の相違が，重 合後のレジン試験片にに゙のような影響を及ぼすか検討し て, 次の結論を得た。

1. 型材として用いた超硬石こう，シリコーン，寒天 の熱伝導を測定すると，同一条件下では，超硬石こうが 最も熱伝導がよく，次に寒天，シリコーンの順であっ た。

2. レジン試験片の寸法精度と適合性は, plaster core method, silicone core method のいずれも加 熱重合型レシンよりも常温重合型レジンの方が優れてい た。

3. 型材の相違からみると, silicone core method は表面が滑沢なため, 内部応力の発生量を抑えることが できるが, 寸法精度, 適合性の面からは, plaster core methodに比べやや少っていた.

4.レジ重合に際しての加熱という因子が，重合後 のレシン試験片の寸法精度，適合度に影響を及ぼした。

5. 重合後のレジン試験片の水中保存温度を高くする と, 内部応力の解放は早く経時的な変化量は大きくなっ た。

6.レシン試験片の形状の相違からみると，口蓋の浅 いタイプのレシン試験片の方が深いタイプのものより， 離型直後の変形率と経時的な変化量は小さくなった。

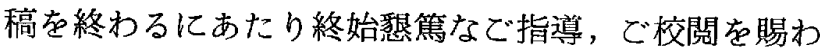
った恩師豊田静夫教授に対し，深甚なる謝意を表します とともに，奏験上数多くので教示をいただいた九州歯科 大学理工学教室林一郎教授, 井上睠一郎助教授に心から 感謝の意を表しますままた，終始実験にご協力いただい た，補経学教室員諸兄に愿く御礼討し上げます。

\section{引用 文 献}

1. 永井一夫：アクリックレジンの再検討, 菌界展望 4 : 16-17, 1947.

2. 加藤仁朗・西井正道・他：各種ヒートショック型休 用樹脂の 比較検討, 䨑材器誌 $17: 51-60$, 1968.

3. 藤井正道・堀部隆・他：加熱重合法と義画床用レジ ンの性質, 䨑材器誌 $17: 28-34,1968$.

4. 金竹暂也：雪科理工学通論, 末永書店, 東京,
$1962,229-256$.

5. Shepard, W. L. : Denture bases processed from a fluid resin, J. Prosthet. Dent. $19: 561-572,1968$.

6. Jeffreys, F. E. : Use of self-curing resins in repairing and relining denture, J.A. D. A. $44: 298-301,1952$.

7. McCracken, W. L. : Auxiliary uses of cold curing acrylic resins in prosthetic dentistry, J. A. D. A. 47:298-304, 1953.

8. Stanford, J. W. and Burns, C. L. : Selfcuring resins for repairing dentures, J. A. D. A. $51: 307-315,1955$.

9. Brauer, G. M. and White, E. E. : Denture reliners-direct, hard, self-curing resin, J. A. D. A. $59: 270-283,1959$.

10. Anthony, D. H. and Peyton, F. A. : Dmensional accuracy of various denture-base materials, J. Prosthet. Dent. 12:67-81, 1962 .

11. Mowery, W. E. and Burns, C. L. : Dimensional stability of denture base resins, J. A. D. A. $57: 345-353,1958$.

12. Woelfel, J. B. and Sweeney, W. T. : Some physical properties of organic denture base materials, J. A. D. A. $67: 489-$ $504,1963$.

13. 河合庄治郎・野首孝峝：注入型レシンによる補緅に ついて，歯科時報 $24: 12-19 ， 1970$ 。

14. 奥野善彦・丸岡寛昭・他：注入型レシンに関する基 礎的研究，阪大雬誌 $17: 45-55 ， 1972$.

15. 安田 登・増原英一・他：流し込みレシンのスプル 一形熊と重合収縮, 人工畨の移動, 柬界展望 $44: 498-512,1974$.

16. 奥野善彦・野首孝萂：特殊石乙うを使用した新しい 注入型レシン重合法，柬界展望 $47: 182-$ 196, 1976.

17. 熱田 充・増原英一・他：流し込み法による正確な レジン休のつくり方, DE 17:4-14, 1971 .

18. 鈴木 朠・宮治俊幸・他：寒天型によるレジン重合 の 2,3 の問題, 歯材器誌 $29: 74-80$, 1973 . 
19. 三浦維四・林一郎・他: スキンナ一雪科材料学, 医 歯薬出版, 東京, 1969, 131-182.

20. Schroeder, A. : Die Eignung der Methakrylate als Prothesenstoffe im Lichte neuer Unterschung, Schweiz. Mschr.

Zahnheilk. $63: 961-971,1953$.

21. 三宅茂樹：歯科用レジン重合時に発生する内部応力 に関する研究, 九霜誌 $31: 471-485,1978$.

22. 原田義雄：義歯床用常温重合樹脂に関する研究，口 病誌 $32: 291-312,1965$.

23. Woelfe1, J. B. and Paffenbarger, G. C. : Pressure-indicatore-paste patters in duplicate dentures made by different processing techniques for the same patients, J. A. D. A. $70: 339-343,1965$. 24. Young, J. M. : A study of the accuracy of the apposition of palatal tissues to complete dentures, J. Prosthet. Dent. $23: 136-147,1970$.

25. Woelfel, J. B. and Paffenbarger, G. C. : Dimensional changes in complete dentures on drying, wetting and heating in water, J. A. D. A. $65: 495-505$, 1962 .

26. Woelfel, J. B. and Paffenbarger, G. C. : Dimensional changes occuring in dentures during processing, J. A. D. A. $61: 413-430,1960$.

27. 丸岡寬昭：石高模型の膨張がレジン休の適合度に及 ぽす影響に関する研究，阪大歯誌 $16 ： 29-43$, 1971 .

28. Smith, D. E., Lord, J. L., et al. : Complete denture relines with auto-polymerizing acrylic resin processed in water under air pressure, J. Prosthet. Dent. 18:103 $-115,1967$.

29. 中井宏之・辻合和雄・他：義歯床作製時の諸条件が その再現性に及ぼす影響について（その2）， 雨材器誌 $16: 239-250,1967$.

30. Osborne, J. : Internal strains in acrylic denture base materials, Brit. Dent. J. $16: 204-212,1947$. 